\title{
Bacteriological Investigation of S . Aureus in Urinary Tract Infection in South Port Said City
}

\author{
Ahmed M. Abdelaty ${ }^{1 *}$, Mahmoud M. Zaki ${ }^{1}$, Amro S. Hanora ${ }^{2}$ and Magdy Bahgat ${ }^{3}$ \\ ${ }^{1}$ Botany Department, Faculty of Science Port Said University Egypt \\ ${ }^{2}$ Microbiology and Immunology Department, Faculty of Pharmacy, Suez Canal University, Egypt. \\ ${ }^{3}$ College of pharmacy, Jazan university, Saudi Arabia \\ Received: 30 April 2018 /Accepted: 12 May 2018 \\ * Corresponding author: a.sokarno@yahoo.com
}

\begin{abstract}
UTI is characterized by the evidence of uropathogens and pyuria and is accompanied by various clinical manifestations depending on the area of involvement. The aim of this study - was to isolate the bacterial infection to urinary tract infection in men and women at different ages and to investigate the susceptibility of bacteria implicated in urinary tract infection to different antimicrobial drugs (antibiotics).Also to determine minimum inhibitor concentration for resistant bacteria to antibiotic and molecular characterization of $S$. aureus associated . Materials and methods :One hundred urine specimens were received from patients admitted during January till December 2015. S. aureus isolates were confirmed by typical colonial morphology, and identified by differential tests as well as by the growth on characteristic agar, Susceptibility testing was carried out by disk diffusion method. Among the 100 isolates, 6 bacterial strain was isolated from the urine specimens of infected Patient admitted at Port-said area out-patient clinics, using agar medium and macCkonkey agar, This organism was characterized by biochemical tests and showed similarity with $S$. aureus . The genomic level confirmation done with $16 \mathrm{~S}$ rDNA primer by submitting the genomic sequence to Gene Bank under acc.No-GU046545 after comparing, showed $98 \%$ sequence similarity with $S$. aureus . Antibiotic susceptibility test revealed that Amikacin, Amoxicillin and Imepenem are the lowest resistant rate with percent of 100, 83 and 66\% respectively and Ciprofloxacin showed the highest resistant rate with $84 \%$. Pattern on antibiotic susceptibility test showed high resistant rate to some antibiotic that made it difficult for pregnant patients, although its frequency was low. The most prevalent Gram positive bacterial pathogen in Port-saed city was $S$. aureus and the most sensitive antibiotic against it is Amikacin.
\end{abstract}

Keywords: Antibiotic sensitivity, Molecular characterization, Minimum inhibitor concentration

\section{Introduction}

Urinary tract infection (UTI) is one of the most important causes of morbidity in the general population, and is the second most common cause of hospital visits[1]. The pathogenic causing UTIs are almost always predict table[2].

In recent studies microbial species that cause UTIs are classified by their target sites, such as urine infection (bacteriuria), bladder infection (cystitis) and kidney infection (pyelonephritis), which can be either asymptomatic or associated with symptoms [3].. Prevalence of infection differs with age, sex and certain predisposing factors, and The distribution of these bacteria is different in different parts of the world [4]. 
Urinary Tract Infections involve the infection of kidneys, ureters, bladder, and/or urethra by pathogenic organisms invasion of the urinary tract, which ultimately leads to an inflammatory response of the urothelium. Prevalence of infections may differ with age, sex and certain predisposing factors. The incidence of infection is greater in females than in males with two exceptions, infections found in infants and catheter-related infections. Women tend to become infected by UTIs more often because their urethra is shorter and closer to the anus than men and hence, the pathogenic bacteria have easier access to the bladder [4]. The gram positive bacterium S. aureus is an opportunistic pathogen which can cause a spectrum of diseases, ranging from relatively minor skin and soft tissue infections to serious fatal infections such as toxic shock syndrome, pneumonia, bacteraemia and sepsis. Increased effort in the field of $S$. aureus research over the last decade has not yet resulted in a reduction in morbidity due to $S$. aureus associated disease1 [5].

Table 1: The antimicrobial agents used for sensitivity tests.

\begin{tabular}{l|c|c|c|c|c}
\hline $\begin{array}{l}\text { Antimicrobial } \\
\text { agents } \\
\text { (antibiotic } \\
\text { discs) }\end{array}$ & Symbol & \multirow{2}{*}{$\begin{array}{c}\text { Conc. } \\
(\mu \mathrm{g})\end{array}$} & & \multicolumn{3}{|c}{\begin{tabular}{l} 
Diameter of inhibition \\
\cline { 4 - 6 }
\end{tabular}} & $\mathrm{R}$ & $\mathrm{I}$ & $\mathrm{S}$ \\
\hline Amikacin & $\mathrm{AK}$ & 30 & $\leq 14$ & $15-16$ & $\geq 17$ \\
\hline Ampicillin & $\mathrm{AMP}$ & 10 & $\leq 13$ & $14-16$ & $\geq 17$ \\
\hline Tobramycin & TOB & 10 & $\leq 12$ & $13-14$ & $\geq 15$ \\
\hline Ciprofloxacin & $\mathrm{CIP}$ & 5 & $\leq 15$ & $16-20$ & $\geq 21$ \\
\hline Gentamicin & $\mathrm{CN}$ & 10 & $\leq 12$ & $13-14$ & $\geq 15$ \\
\hline Imipenem & IPM & 10 & $\leq 13$ & $14-15$ & $\geq 16$ \\
\hline Amoxicillin & AMX & 30 & $\leq 13$ & $14-18$ & $\geq 19$ \\
\hline Nitrofurantion & $\mathrm{F}$ & 300 & $\leq 14$ & $15-16$ & $\geq 17$ \\
\hline Norfloxacin & NOR & 10 & $\leq 12$ & $13-16$ & $\geq 17$ \\
\hline $\begin{array}{l}\text { Trimethoprim } \\
+ \text { sulpha }\end{array}$ & SXT & 1.25 & $\leq 10$ & $11-15$ & $\geq 16$ \\
\hline
\end{tabular}

Multiple prospective cohort studies have shown that carriers are at about three fold higher risk of invasive $S$. aureus disease than noncarriers, most commonly due to their carried strain[5,9]. Although frequently considered a skin coloniser, S. aureus is a common member of the gastrointestinal (GI) tract flora: detectable GI tract carriage is about $60 \%$ in nasal carriers[6]. However, this may be an underestimate, as $S$. aureus is a minority population in the bowel and its detection may be influenced by culture techniques used [7]. S. aureus is relatively uncommon cause of urinary tract infection in the general population[8].

In certain patient $S$. aureus cause ascending urinary tract colonization and infection.
Urinary tract instrumentation and the presence of an indwelling catheter increase the risk of S. aureus carriage in the urinary tract [10]. The majority of cases of S. aureus bacteriuria are not associated with symptoms of urinary tract infection [8] because bacteriuria nearly universally occurs concomitantly with long-term urinary catheterization [11]. The clinical significance of isolation of $\mathrm{S}$. aureus from the urine is undefined in such patient. Although urinary $S$. aureus may be the source of staphylococcal bacteremia [12]. S. aureus is a common component of normal human flora, with approximately $20-25 \%$ of the adult population described as persistent nasal carriers[9]. Identification of bacterial isolates is an essential task of clinical microbiology laboratories. In clinical laboratories, the present means of identification of bacteria relies on phenotypic tests. Traditional phenotypic identification is difficult and time consuming [4].In the late 1906 1910, genotypic identification emerged as an alternative or complement to the established phenotypic methods. Typically, genotypic identification of bacteria involves the use of conserved sequences within phylogenetic ally informative genetic targets, such as the smallsubunit (16S) rRNA gene. Sequence analysis of the 16S ribosomal RNA (rRNA) gene has been widely used to identify bacterial species and diagnose microbial infections. However, these methods are yet to replace standard bacterial culture due to their prohibitive costs, complexity, and the need for highly-trained personnel [14]. The present study aims at analyzing the infectious epidemiology of UTIs in a general university hospital located in South Port Said city, In addition, it examines the susceptibility profiles of $S$. aureus between January and December of 2015, studying Minimum inhibitory concentration of antibiotic and molecular characterization of $S$. aureus associated.

\section{Methodology:}

\section{Sample collection}

Study period : This is a cross-sectional study carried out in outpatient clinic of south port-said city. One hundred urine specimens were received from patients during January till December 2015 . This specimens were obtained as clean catch voided or catheterized samples from all patients who were subjected for assessment for UTI. 


\section{Isolation and Identification of bacterial isolate}

All specimens were cultured routinely in Microbiology Laboratory on Blood nutrient, MacConkey's, Cled and EMB agar and were incubated at $37^{\circ} \mathrm{c}$ for $24 \mathrm{hr}$. All E. coli isolates were confirmed by typical colonial morphology, type of hemolysis, Gram stain, motility, microscopic examination, growth characteristics in agar and biochemical tests including indole, methyl red, Vogues-Proskauer and citrate (IMViC), triple sugar iron, urease, and nitrate reduction [15]. A specimen was considered positive for UTIs if an organism were cultured at a concentration of at least $10^{5}$ single bacteria colonies per $\mathrm{ml}$ of urine and $>5$ pus cells per high power field were observed on microscopic examination[11].

Table 2: All bacterial species isolated from different ages and different sexes in 100 urine sample which are positive for bacteria.

\begin{tabular}{|c|c|c|c|c|}
\hline \multirow[t]{2}{*}{$\begin{array}{l}\text { Patient } \\
\text { age } \\
\text { (years) }\end{array}$} & \multirow[t]{2}{*}{$\begin{array}{c}\text { No of } \\
\text { BI }\end{array}$} & \multicolumn{2}{|c|}{$\begin{array}{l}\text { BI in } \\
\text { different } \\
\text { sexes }\end{array}$} & \multirow[t]{2}{*}{ Bacterial isolates } \\
\hline & & $\mathrm{M}$ & $\mathrm{F}$ & \\
\hline $0-10$ & 15 & 7 & 8 & $\begin{array}{l}\text { E. coli , Klebsiella } \\
\text { pneumoniae , Pseudomonas } \\
\text { areuginosa }, \quad \text { Proteus } \\
\text { mirabilis and Enterococcus } \\
\text { spp }\end{array}$ \\
\hline $10-20$ & 6 & 4 & 2 & $\begin{array}{l}\text { E. coli , Klebsiella } \\
\text { pneumoniae and Proteus } \\
\text { vulgaris. }\end{array}$ \\
\hline $20-30$ & 5 & 3 & 2 & E. coli \\
\hline $30-40$ & 15 & 5 & 10 & $\begin{array}{l}\text { E. coli , Klebsiella } \\
\text { pneumoniae } \\
\text { Staphylococcus aureus and } \\
\text { Enterococcus spp. }\end{array}$ \\
\hline $40-50$ & 20 & 8 & 12 & $\begin{array}{l}\text { E. coli , Klebsiella } \\
\text { pneumoniae , Pseudomonas } \\
\text { areuginosa }, \quad \text { Proteus } \\
\text { mirabilis and Enterococcus } \\
\text { spp. }\end{array}$ \\
\hline $50-60$ & 18 & 6 & 12 & $\begin{array}{l}\text { E. coli , Klebsiella } \\
\text { pneumoniae , Pseudomonas } \\
\text { areuginosa , Proteus } \\
\text { vulgaris , Staphylococcus } \\
\text { aureus and Enterococcus } \\
\text { spp. }\end{array}$ \\
\hline $60-70$ & 14 & 5 & 9 & $\begin{array}{l}\text { E. coli , Klebsiella } \\
\text { pneumoniae, Pseudomonas } \\
\text { areuginosa and Proteus } \\
\text { mirabilis. }\end{array}$ \\
\hline $70-80$ & 5 & 3 & 2 & $\begin{array}{l}\text { E. coli , Klebsiella } \\
\text { pneumoniae } \\
\text { Staphylococcus. } \\
\text { Klebsiella pneumoniae and } \\
\text { Proteus mirabilis. }\end{array}$ \\
\hline $80-90$ & 2 & 1 & 1 & $\begin{array}{l}\text { E. coli and Klebsiella } \\
\text { pneumonia. }\end{array}$ \\
\hline
\end{tabular}

$\mathrm{BI}$ : bacterial Isolate.

\section{Antibiotic susceptibility Testing:}

Susceptibility testing was carried out by disk diffusion methods recommended by CLSI, All $E$. coli isolates were tested for resistance against gentamicin, ampicillin, ciprofloxacin, tobramycin, trimethoprimsulphamethoxazole, Imipenem, norofloxacine, amikacin, nitrofurantoin and amoxicillin, antimicrobial susceptibility and resistance was determined by isolate growth zone diameter.

$E$ test are used for determination of Minimum inhibitor concentration (MIC) : The lowest concentration which can inhibit growth of bacteria.

\section{Molecular characterization of bacterial isolate by $16 \mathrm{SrDNA}$ gene.}

The DNA was extracted from the bacterial isolate by the method of Sambrook et al. (2001).

The polymerase chain reaction was carried out by following method of Sambrook and Russel(2007). forward primer 5' TAGGGAAGTAATGACGG 3' Reverse primer5' CCTCTATCCTCTTTCCAACC3' was used in PCR reaction.

\section{Automated sequencing:}

The sequencing of the genomic DNA amplicon coding for strain TS1 was carried out at Biotechnology center, Suez Canal University by 16S rRNA gene sequence analysis, PCR gene fragment of 16S rRNA was amplified from the purified genomic DNA using the universal primer. Aliquots of the amplification products were analyzed by agarose gel electrophoresis using $1.0 \%$ agarose containing $0.5 \mu \mathrm{g}$ of ethidium bromide per $\mathrm{ml}$. The results of Blast $\mathrm{n}$ for $16 \mathrm{~S}$ rRNA DNA sequences were retrieved and aligned with the sequences of bacterial isolates using Clustal W embedded in MEGA 6 (Molecular Evolutionary Genetics Analysis) software. The multiple sequence alignment and 16S rRNA phylogenetic tree was constructed. Phylogenetic analysis was conducted based upon 16S rRNA gene data using Maximum Likelihood analyses (ML). Alignment gaps were treated as missing data. ML analysis was conducted using a heuristic search with tree bisection- reconnection(TBR) branch swapping and 100 random addition sequence replicates. Statistical support for the internal branches was estimated by bootstrap analysis based upon 1000 replications. Nucleotide sequence was compared to those in the Gene Bank 
database with Basic Local Alignment Search Too (BLAST algorithms to identify known closely related sequences. The tree was generated by the neighboring algorithm (SaitouandNei1987) join edtoit by implementation with phydit. The assemblage of 16SrDNA gene sequences in each library was analyzed by rarefaction analysis

\section{Results:}

In this study, One hundred patients were showed to be urine culture positive (their colony count was equal or more than $10^{4}$ ). The frequency of isolated microorganisms and their relation to sex is given in Table 3. The most common isolated uropathogens in Gram-negative bacilli were $E$. coli $(72 \%)$ and Gram-positive cocci were $S$.aureus $(6 \%), E$. coli were isolated in high frequencies in females $(63.8 \%)$ and $(36.2 \%)$ in male. Also $E$. coli present in all ages from five months to 90 years But with same frequency male and female as shown in Table (3).

Table 3: Resistant and susceptibility of Gram positive bacterial isolates to various antibiotics, indicating sex and age of each individual infected with $S$. aureus in the 6 sample, were Symbol S are Sensitive ,Symbol R are Resistant and I are intermediate

\begin{tabular}{|c|c|c|c|c|c|c|c|c|c|c|}
\hline Tested antibiotics & 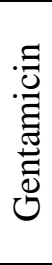 & 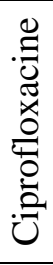 & 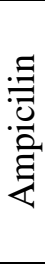 & 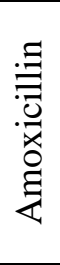 & $\begin{array}{l}\text { : } \\
\frac{\pi}{\tilde{J}} \\
\frac{\mathrm{g}}{\mathrm{Z}}\end{array}$ & 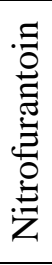 & 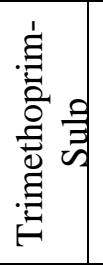 & 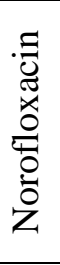 & 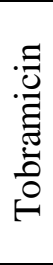 & 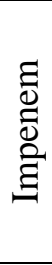 \\
\hline Staphylococcus aureus (Sa.1) & $\mathrm{R}$ & $\mathrm{R}$ & $\mathrm{R}$ & $\mathrm{S}$ & $\mathrm{S}$ & $\mathrm{S}$ & $\mathrm{R}$ & $\mathrm{S}$ & $\mathrm{R}$ & $\mathrm{S}$ \\
\hline Staphylococcus aureus (Sa.2) & $\mathrm{S}$ & $\mathrm{S}$ & $\mathrm{R}$ & $\mathrm{S}$ & $\mathrm{S}$ & $\mathrm{S}$ & $\mathrm{S}$ & $\mathrm{R}$ & $\mathrm{S}$ & $\mathrm{R}$ \\
\hline Staphylococcus aureus (Sa.3) & $\mathrm{S}$ & $\mathrm{R}$ & $\mathrm{S}$ & $\mathrm{R}$ & $\mathrm{S}$ & $\mathrm{R}$ & $\mathrm{R}$ & $\mathrm{S}$ & $\mathrm{R}$ & $\mathrm{S}$ \\
\hline Staphylococcus aureus (Sa.4) & $\mathrm{R}$ & $\mathrm{R}$ & $\mathrm{S}$ & $\mathrm{S}$ & $\mathrm{S}$ & $\mathrm{R}$ & $\mathrm{R}$ & $\mathrm{R}$ & $\mathrm{R}$ & $\mathrm{S}$ \\
\hline Staphylococcus aureus (Sa.5) & $\mathrm{S}$ & $\mathrm{R}$ & $\mathrm{S}$ & $\mathrm{S}$ & $\mathrm{S}$ & $\mathrm{S}$ & $\mathrm{R}$ & $\mathrm{R}$ & $\mathrm{S}$ & $\mathrm{S}$ \\
\hline Staphylococcus aureus (Sa.6) & $\mathrm{S}$ & $\mathrm{R}$ & $\mathrm{R}$ & $\mathrm{S}$ & $\mathrm{S}$ & $\mathrm{R}$ & $\mathrm{R}$ & $\mathrm{R}$ & $\mathrm{S}$ & $\mathrm{R}$ \\
\hline
\end{tabular}

\section{Susceptibility of S. aureus against different antibiotic:}

The results revealed that isolates of $S$. aureus were highly sensitive to amikacin $100 \%$, amoxicillin $83 \%$ and imepenem with percentage of $66 \%$, but were highly resistant to ciprofloxacin $84 \%$, trimethoprim + sulphameth-oxazole with $84 \%$ as shown in Table (1).

\section{Minimum inhibitor concentration $(M I C)$ :}

(MIC) of five antibiotic drugs (Ampicillin, Amikacin,Gentamicin, Clindamycin and Imipenem ) of the tow clinical resistant bacterial strains was determined and these results were illustrated (Table2) . MIC of Clindamycin was $(300 \mu \mathrm{g} / \mathrm{ml})$ for tow strain S. aureus(4 and 5). The maximum MIC of Ampicilin was obtained at concentration $(1 \mu \mathrm{g} / \mathrm{ml})$ for $S$. aureus isolate no 6 , and the minimum was obtained at $(0.2 \mu \mathrm{g} / \mathrm{ml})$ for S. aureus 4. MIC for Amikacin was $(1.5 \mu \mathrm{g} / \mathrm{ml})$ for $S$. aureus 6 , and $S$. aureus 4 . The maximum MIC of Gentamicin was obtained at concentration $(1.0 \mu \mathrm{g} / \mathrm{ml})$ for $S$. aureus isolate no 6 . and the lowest was obtained at $(0.75 \mu \mathrm{g} / \mathrm{ml})$ for $S$. aureus isolate no 4.MIC of Imipenem was the highest $(0.45 \mu \mathrm{g} / \mathrm{ml})$ for $S$. aureus isolate no 4 and the lowest $(0.19 \mu \mathrm{g} / \mathrm{ml})$ for $S$. aureus isolate no 6 .

Table 4: Minimum inhibition concentration of the most resistant bacteria to some antibiotics .

\begin{tabular}{c|l|c|l|l|l}
\hline \multirow{2}{*}{ No of Isolate. } & \multicolumn{5}{|c}{ Concentration of Antibiotic $(\mu \mathrm{g} / \mathrm{ml})$} \\
\cline { 2 - 6 } & $\mathrm{AM}$ & $\mathrm{AK}$ & $\mathrm{Cn}$ & $\mathrm{CL}$ & $\mathrm{IMP}$ \\
\hline S. aureus (4) & 0.2 & 1.5 & 1.0 & 300 & 0.45 \\
\hline S. aureus (6) & 1.0 & 1.5 & 0.75 & 300 & 0.19 \\
\hline
\end{tabular}

\section{Molecular characterization of bacterial isolated from Urine:}

The PCR product that was run in agarose gel electrophoreses showed 870bp for strain. The DNA sequence of the strain having Gene Bank ACC.NO.GUO46545 when compared to those in Gene bank databases with BLAST were found to have $98 \%$ similarities with S.aureus .This strain is named as S.aureus (Gene bank ACC.No.GU046543).

\section{Molecular characterization of the strain:}

The genomic DNA was amplified with16S rDNA primer, 16S F:5'-GAGTTTGATCCTGGCTTAG- 


\section{3'16S R:5'-GGTTACCTTGTTACGACTT-3' .} DNA sequence revealed that it is high purified sequence, The amplified PCR product when run in agarose gel electrophoresis, strain TS1 was found having a molecular weight approximately of 870 bp when compared with the DNA marker (Figure $1)$.

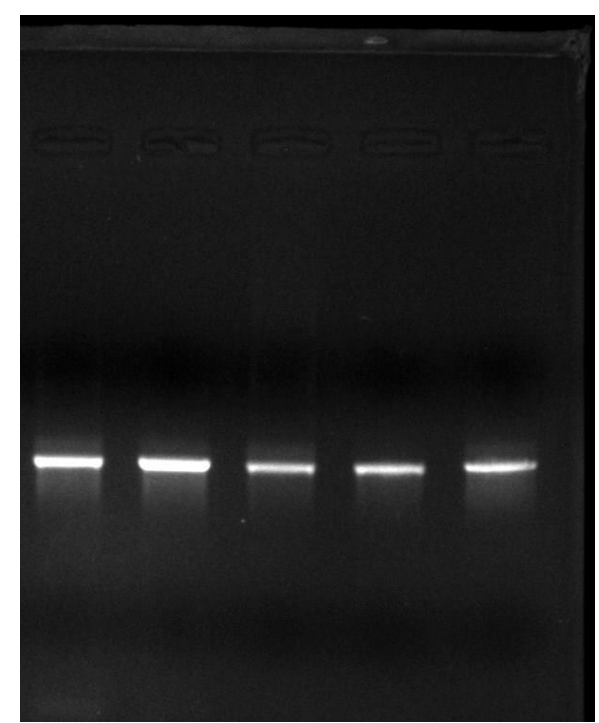

Figure 1 : Agarose gel analysis. An unknown amount of a $5.5 \mathrm{~kb}$ DNA fragment (U) was run alongside known quantities (as indicated in ng )of the same DNA fragment. The unknown sample contained 75-100 ng DNA, as estimated by visual comparison with the standards M: $1 \mathrm{~kb}$ DNA ladder

\section{The phylogenetic tree showed resemblance with S. Aureus.}

PCR amplified 16 SrRNA gene using 27F-1429R Primer Pairs were sequenced by Sanger sequencing method. sequences were used for phylogenetic tree construction of UTI isolates. This sequences were used for construction of phylogenetic tree as illustrated in Figure (2).

The evolutionary history was inferred by using the maximum likelihood method based on kimura 2parameter model (kimura 1980). . The tree with the highest $\log$ likelihood is shown. The percentage of trees in which the associated taxa cluster together is showed next to branches. Initial tree for the heuristic search were obtained automatically by applying neighbor- join and BioNj algorithms to matrix of pairwise distances estimated using the maximum composite likelihood (MCL)approach, and then selecting the topology with superior log likelihood value. The tree is drawn to scale, with branch length measured in the number of substitution per site.

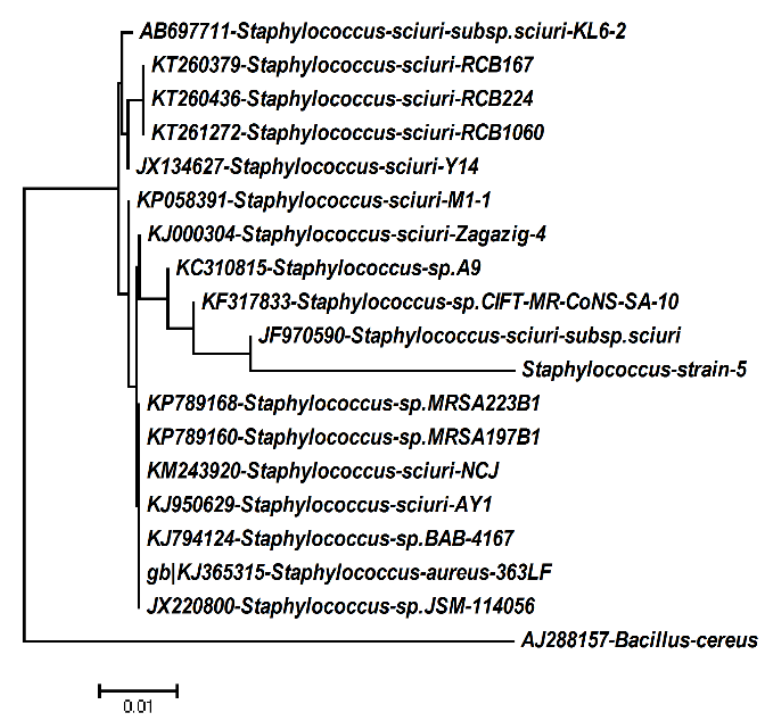

Figure 2.: Phylogenic tree

Phylogenetic analysis The 16s rDNA sequences of the amplified products revealed that the strains TW1 had unique sequences which matched with S.aureus present by phylogenetic tree.

\section{Discussion:}

In the present study a total of 250 urine samples were collected from patients who were examined for UTIs in South Port said hospitals or attending South earth Port said outpatients clinics, then cultured on CLED agar, blood agar and MacConkey agar media. The results of this study corroborated that $40 \%$ of samples ( 100 out of 250 ) gave positive bacterial growth when cultivated in CLED agar media. A positive bacterial growth was based on the presence of $\geq 10^{4} \mathrm{CFU}$ per $\mathrm{ml}$ in urine culture. Significant bacteriuria occurs when there are $10^{5}$ colony forming unit per $\mathrm{ml}$ $(\mathrm{CFU} / \mathrm{ml})$ in a properly collected urine [16].

This study were consistent with other studies which showed that $S$. aureus is relatively infrequent urinary tract isolate in the general population accounted for $6 \%$ of isolates[17].

A similar laboratory based study conducted in France found that S. aureus accounted for only $1 \%$ of isolate from urine specimen submitted from the community[18].Mylotte et al reported that \% of bacteremic episode with urinary tract infection as the patient source were caused by MRSA as determined on the basis of symptoms and concomitant isolation of MRSA from urine sample the specific urinary tract symptoms supporting a diagnosis of urinary tract infection were not given [19]. Thus significant problem with interpreting prior studies lies in the inherent difficulty in making a definitive diagnosis of 
urinary tract infection in the long - term care population for example capitano et al. [20]. Bacterial infection are considered the main source of the disease and E. coli is considered to be the predominating pathogen like proteus $\mathrm{Sp}$, klebsiella sp, and Entero sp, have a minor role in conferring the disease,However $S$. aureus is colonizing the perineum of the women during pregnancy can't be denied and is highly resistant to antimicrobial agent [21]. Women with recurrent UTI have an increased susceptibility to Vaginal colonization and uropathogens, which is due to a greater propensity for uropathogenics coliforms to adhere to uroepithelial cells [22]. In the present investigation the antibiotics used were Impenem, norfloxacin, amikacin, Amoxicillin, Tobramicin, nitrofurantion, Ciprofloxacin, gentamicin, Ampicillin and trimethoprim-sulphamethoxazole . Amikacin and amoxicillin were highly active towards S. aureus but were highly resistant to ciprofloxacine and trimethoprimsulphamethoxazole. The results of the present study showed that the susceptibility rate of urinary isolates was highest for amikacin (100\%), followed by amoxicillin (83\%), imepenem (66 $\%)$, . Meanwhile, the resistant rate of urinary isolates was highest for ciprofloxacin $(84 \%)$ and trimethoprim-sulphamethoxazole $(84 \%)$. The increasing frequency of trimethoprimsulfamethoxazole (TMP-SMX) resistance is worrisome, it is unlikely in-tranasal mupirocin would have any effect on urinary colonization in any event -systemic therapy with antimicrobial agent that are excreted in the urine is possible approach but the result of the limited clinical trials involving this Patient Population has been disappointing for example the combination of rifampin and minocycline had a high failure rate with regard to eradicating MRSA in long term care[23]. Bayam Behzadi demonstrated that $S$. aureus caused $6.6 \%$ of urinary tract infections 48 $.6 \%$ in men and $51.4 \%$ in women [24]. Wilson and coworkers documented the paucity of staphylococcal antigen-reactive plasmablasts recoverable from the peripheral blood of patients with active $S$. aureus infections associated with different clinical syndromes during S. aureus infection [25]. Overall, our results argue against the notion that clinical S. aureus infection is responsible for a global functional defect in the generation of antigen-reactive memory B cells, and therefore complement findings of abundant T cell memory against S. aureus [26]. Kruth $S$ demonstrated that routine MIC determination has clinical and research benefit over disc diffusion testing and allow pharmacodynamics principles to be applied when designing evidence based dosing regimen for example low level B lactamase resistance in organisms causing urinary tract infection can be overcome by high urine drug concentration[27].In conclusion, the PCR method provides a valuable tool for cheap and accurate diagnosis of Gram-negative bacteria and Gram - positive in urinary tract infections, and can also be applicable for other infections.

\section{Conclusion:}

The most prevalent Gram positive microorganism which cause urinary tract infection in South Port Said city are $S$. aureus, and the most sensitive antibiotic against it are Amikacin, and the most resistant against S.aureus are Ciprofloxacin. the minimum MIC for Ampicillin are $0.2 \mu \mathrm{g} / \mathrm{ml}$ and the maximum MIC for Ampicillin are $1.0 \mu \mathrm{g} / \mathrm{ml}$. The 16SrDNA sequence of the amplified product revealed that the strain TW1 had a unique sequence which matched with $S$. aureus present by phylogenetic tree.

\section{Reference:}

Ronald, A.R. and Pattulo, M.S. The natural history of urinary infection in adults. Med Clin North Am., (1991) 75:299-312

Nicole,L.E. Epidemiology of urinary tract infection, journal of infection medicine (2001) 18,153-162

Piranfar, V. Mirnejad R, Erfani M. Incidence and Antibiotic Susceptibility Pattern of Most Common Bacterial Pathogen Causing Urinary Tract Infection (UTI) in Tehran, Iran, 2012-2013. Int J Entric Pathog.2014;2(1):e24779

Noor,A.F., Shams F, Kishore S, Hassan MM., Noor R. Prevalence and antibiogram profile of uropathogens isolated from hospital and community patients with urinary tract infection in Dhaka city. J Bangladesh Aca Sci. 2013;37(1):57-63.

Nouwen, J. L. et al. Predicting the Staphylococcus aureus nasal carrier state: derivation and validation of a "culture rule". Clinical infectious diseases: an official publication of the Infectious Diseases Society of America(2004) 39, 806-811.

Acton, D. S., Plat-Sinnige, M. J., van Wamel, W., de Groot, N. \& van Belkum, A. Intestinal carriage of Staphylococcus aureus: how does its frequency compare with that of nasal carriage and what is its clinical impact? European journal of clinical microbiology \& infectious diseases: official publication of the European Society of Clinical Microbiology(2009) 28, 115-127, . 
Sollid, J. U., Furberg, A. S., Hansen, A. M. \& Johannessen, M. Staphylococcus aureus: determinants of human carriage. Infection, genetics and evolution: journal of molecular epidemiology and evolutionary genetics in infectious diseases(2014) 21, 531-541 .

Demuth PJ, Gerding. GN, Crossly K. Staphylococcus aureus bacteriuria. arch intern med.1979.vol.139P(Pg.78-80).

Hryniewicz, K. and Sulikowska, A . Antibiotic susceptibility of bacterial strains isolated from urinary tract infections in Poland. J Antimicrobial Chemotherapy ( 2001) 47:773-780

Coll ,PP.,Crabtree, B.F.,O Conner PJ, Klenzak S. Clinical risk factor for methicillin -resistant Staphylococcus aureus bacteriuria in askilled -care nursing home, arch fam med,1994,vol 3(Pg.357-60)

Warren,J.W, Damron D,Tenney JH, Hoopes JM, Deforge B, Muncie HL, fever bacteremia, and death as complication of bacteriuria in women in long term urethral catheter, J infect Dis,1987.vol (Pg 1151-8)

Mylott, J.M,Tayara, A., Goodnough S. Epidemiology of bloodstream infection in nursing home resident :evaluation in a large cohort from multiple home, clin infect dis,2002, vol 35.(pg1484-90)

Kass, E.H. Bacteriuria and the diagnosis of infection of urinary tract. Arch. Intern. Med.1956,100: 709- 71

Tamim, M.M.; Alesseh, H. and Aziz, H. Analysis of the efficacy of urine culture as part of sepsis evaluation in the premature infant. Pediatr Infect Dis J., (2003). 22:805-808.

Yuksel, S.; Ozturk, B.; Kavaz, A.; Ozcakar Z.B.; Acar, B.; Guriz, H, Aysev, D. Ekim, M. and Yalcinkaya, F. Antibiotic resistance of urinary tract pathogens and evaluation of empirical treatment in Turkish children with urinary tract infections. Int. J. Antimicrob. Agents., (2006). 5: 413-416.

Das, R.N.; Chandrashekhar, T.S.; Joshi, H.S. Gurung, M.; Shrestha, N. and Shivananda, P.G .Frequency and susceptibility profile of pathogens causing urinary tract infections at a tertiary care hospital in western Nepal. Singapore Med J. . (2006)., 47(4): 281-285.

Barett, S .P.,Savage M.A., Rebec M.P.,Goyot a,
Andrew n,Shrimpton S.B. antibiotic sensitivity of bacteria associated with community acquired urinary tract infection in Pritian, $\mathrm{j}$ antimicrob chemother 1999, vol 44(359-65

Goldstein, F.W. Antibiotic susceptibility of bacterial strains isolated from Patient with community acquired urinary tract infection in France eur $\mathrm{j}$ clin microbial infect dis 2000, vol 19(Pg 112-7)

Mylott, J.M.,Tayara, A., Goodnough, S. Epidemiology of bloodstream infection in nursing home resident :evaluation in a large cohort from multiple home, clin infect dis,2002, vol 35.(pg1484-90. )

Capitano, B.,Leshemo A.,Nightingale,C.H,Nicolau pp, cost effect of managing MRSA in a long term care facility-Jam ceriatr soc 2003, vol 5(page 10 -6)

Zalamanovici, T.A.,Creen, H.,Paul M, antimicrobial agents for treating uncomplicated urinary tract infection in women,cochrance database system 2010 Rev (10)

Khotaii, Q, Mamishi, S., Saligeh, R.N. Antibiotic resistance of germs isolated from urinary tract infections. Iran J Pediatr2002;12:28-32.

Muder,P .R .,Boldin,M. P. Brennen,et al a controlled trail of of rifampicin,minocycline and rifampicine Plus minocycline line for eradication of MRSA in long term care Patient, $\mathrm{j}$ antimicrobial chemether 1994. 34,189,90.

Payam, B.M., Elham B. A survey on urinary tract infection associated with three most common uropathogenic bacteria 2010 cited by 53 related article.of amoxicillin-clavulanate and resistance in Escherichia coli over a 4-year period. Infect Control Hosp Epidemiol 1998;19:653-6

Pauli, NT, Kim HK, Falugi F, Huang M, Staphylococcus aureus infection induces protein A-mediated immune evasion in humans. 2014 J Exp Med211:2331-2339.

Kolata,J.B., Kühbandner, I., Link C, The fall of a dogma? Unexpected high T-cell memory response to Staphylococcus aureus in humans. $2015 \mathrm{~J}$ Infect Dis 212:830-838.10.1093/infdis/jiv128

Kruth,S. therapy of selected organ system 2006 pp(372 $-379)$. 